\title{
ANALISIS KESALAHAN BERBAHASA TATARAN SINTAKSIS PADA PENULISAN TEKS EKSPOSISI SISWA KELAS $X$ SMA NEGERI 7 MEDAN TAHUN PEMBELAJARAN 2016/2017
}

\author{
Oleh \\ Eltita Natalia \\ Fitriani Lubis, S.Pd., M.Pd.
}

Penelitian ini bertujuan untuk mendeskripsikan bentuk kesalahan berbahasa tataran sintaksis yang meliputi : (1) kesalahan penggunaan sintaksis berupa frasa pada teks eksposisi siswa kelas X SMA Negeri 7 Medan, (2) kesalahan penggunaan sintaksis berupa kalimat pada teks eksposisi siswa kelas X SMA Negeri 7 Medan.Subjek penelitian ini adalah teks eksposisi siswa kelas X IPS 1 SMA Negeri 7 Medan tahun pembelajaran 2016/2017.Objek penelitian ini adalah kalimat yang mengandung unsur kesalahan sintaksis.Metode penelitian yang digunakan adalah metode deskriptif kualitatif, yaitu mendeskripsikan suatu keadaan alamiah mengenai kesalahan penggunaan sintaksis pada teks eksposisi siswa kelas X SMA Negeri 7 Medan.Untuk menemukan dan mengklasifikasikan kalimat yang mengandung unsur kesalahan sintaksis digunakan teknik membaca dan mencatat.Instrumen pada penelitian ini adalah peneliti sendiri (human instrument).Hasil penelitian kesalahan berbahasa tataran sintaksis pada teks eksposisi siswa kelas X SMA Negeri 7 Medan ada dua. Pertama, kesalahan penggunaan sintaksis berupa frasa sebesar 32,98\% meliputi enam kesalahan, yaitu : penggunaan preposisi yang tidak tepat, susunan kata yang tidak tepat, penggunaan unsur yang berlebihan atau mubazir, penggunaan bentuk superlatif yang berlebihan, penjamakan yang ganda, dan penggunaan bentuk resiprokal yang tidak tepat. Kedua, kesalahan penggunaan sintaksis berupa kalimat sebesar $67,02 \%$ meliputi tujuh kesalahan, yaitu : kalimat yang tidak berpredikat, kalimat yang tidak bersubjek dan tidak berpredikat (kalimat buntung), kalimat yang tidak logis, penggunaan kata tanya yang tidak perlu, urutan yang tidak paralel, penghilangan konjungsi, dan penggunaan konjungsi yang berlebihan.

\section{Kata kunci :kesalahan sintaksis, teks eksposisi}

\section{PENDAHULUAN}

Sebagai kaum terpelajar siswa dan mahasiswa dituntut untuk bisa menggunakan bahasa Indonesia dengan baik dan benar dalam mengkomunikasikan ilmunya. Penentuan atau kriteria berbahasa Indonesia yang baik dan benar itu tidak jauh berbeda 
dengan yang dikatakan sebagai berbahasa baku. Kebakuan suatu bahasa sudah menunjukkan masalah "baik" dan "benar" bahasa itu. Yang paling berperan dalam kegiatan berbahasa adalah orang yang menggunakan bahasa tersebut (Setyawati, 2013 : 9).

Kemampuan berbahasa Indonesia tentu saja dapat ditingkatkan terus-menerus melalui kegiatan belajar dan berlatih menggunakan bahasa Indonesia yang terusmenerus pula. Kita menggunakan bahasa, baik ragam lisan maupun ragam tulis.Bahasa Indonesia ragam lisan lazim digunakan dalam percakapan sehari-hari dan dalam diskusi berbagai pertemuan resmi.Bahasa Indonesia ragam tulis digunakan baik dalam tulisan tidak resmi maupun dalam tulisan resmi.

Kesalahan berbahasa tidak hanya terdapat pada tuturan tetapi juga terdapat pada bahasa tertulis. Hal ini ditinjau dari ragam bahasa berdasarkan sarana pemakaiannya. Dilihat dari segi sarana pemakaiannya, ragam bahasa dapat dibedakan atas ragam lisan dan tulis (Setyawati $2013: 2$ ).

Keterampilan menulis merupakan salah satu keterampilan berbahasa yang bermanfaat bagi kehidupan manusia, khususnya para siswa.Pada saat menulis, siswa dituntut berpikir untuk menuangkan gagasan secara tertulis berdasarkan pengetahuan dan pengalaman yang dimiliki. Kemampuan menulis merupakan ciri orang atau bangsa yang terpelajar (Tarigan,2013: 4). Dalam menulis, siswa diharapkan bisa mengungkapkan pikirannya dengan menggunakan bahasa yang sesuai dengan kaidah bahasa Indonesia.

Bahasa tertulis terikat pada aturan-aturan kebahasaan, seperti ejaan, susunan, sistematika, dan teknik-teknik penulisan. Apabila siswa tidak memenuhi aturan-aturan kebahasaan tertulis, terjadilah kesalahan berbahasa.

Kesalahan berbahasa yang dilakukan oleh siswa dalam proses belajar mengajar mengimplikasikan tujuan pengajaran bahasa belum tercapai secara maksimal. Semakin tinggi kuantitas kesalahan berbahasa itu, semakin sedikit tujuan pengajaran bahasa yang tercapai. Kesalahan berbahasa yang dilakukan oleh siswa harus dikurangi sampai ke batas minimal, bahkan diusahakan dihilangkan sama sekali. Hal ini dapat tercapai jika guru pengajar bahasa telah mengkaji secara mendalam segala aspek seluk-beluk kesalahan berbahasa itu ( Setyawati, 2013:15). 
Dalam pembelajaran bahasa Indonesia masih banyak siswa yang melakukan kesalahan berbahasa. Salah satu kesalahan berbahasa tertulis yang masih sering dilakukan siswa adalah kesalahan berbahasa tataran sintaksis. Ruang lingkup kesalahan berbahasa tataran sintaksis berkisar pada kesalahan frasa, klausa, kalimat dan wacana.

Pada penulisan teks eksposisi siswa dituntut menuangkan gagasannya berdasarkan fakta-fakta yang ada. Pada saat siswa beragumentasi dalam tulisannya kesalahan berbahasa bisa terjadi meskipun pemahaman mengenai unsur kebahasaaan telah dijelaskan oleh guru sebelum menginstruksikan siswa menulis teks eksposisi.

Kesalahan berbahasa yang dilakukan siswa dikarenakan kebiasaan berbahasa yang digunakan di lingkungan tempat tinggal, terpengaruh bahasa yang lebih dahulu dikuasainya, pemakaian bahasa asing, kekurangpahaman siswa terhadap bahasa Indonesia, serta pengajaran bahasa Indonesia yang kurang tepat atau kurang sempurna, sehingga terjadi bentuk yang rancu atau kacau dalam penulisan teks oleh siswa.

Hal ini berdasarkan pengalaman penulis saat melaksanakan Program Pengalaman Lapangan Terpadu (PPLT) di SMA Negeri 7 Medan Tahun Pembelajaran 2016/2017 masih terdapat kesalahan berbahasa tataran sintaksis pada penulisan teks eksposisi oleh siswa. Penulis juga melakukan wawancara dengan guru bahasa Indonesia kelas X SMA Negeri 7 Medan yaitu Aidha Rizkina diperoleh informasi bahwapada penulisanteks eksposisi oleh siswa selalu terdapat kesalahan berbahasa tataran sintaksis.

Kesalahan berbahasa tataran sintaksis ini didukung dengan adanya penelitian Nila Sari (2002) Analisis Kesalahan Sintaksis Bahasa Indonesia Siswa Sekolah Dasar Kabupaten Karo Dalam Mengarang. Hasil penelitian tersebut menunjukkan kesalahankesalahan yang dibuat oleh siswa terutama dalam tataran sintaksis dengan urutan: penggunaan kata depan $(27,99 \%)$, penggunaan kata tugas dan kata sambung $(23,46 \%)$, kesalahan struktur frasa, klausa dan kalimat (19,41\%), penggunaan kata keterangan dan kata paertikel (21.02\%), serta penggunaan urutan kata bilangan ( 8,69\%).

Sejalan juga dengan penelitian yang dilakukan Nurul Isitinganah (2012) Analisis Kesalahan Sintaksis Pada Karangan Narasi Ekspositoris Siswa Kelas VIII SMP Negeri 1 Banguntapan Bantul Yogyakarta. Hasil penelitian ini menunjukkan jumlah kalimat yang mengandung kesalahan sintaksis tersebut terdiri dari kesalahan penggunaan 
struktur frasa sebanyak 95 kalimat $(30,94 \%)$ dan kesalahan penggunaan struktur kalimat sebanyak 196 kalimat $(63,84 \%)$.

Begitu pula dengan penelitian Amalia Ayu Sari (2013) Kesalahan Berbahasa Tataran Frasa Dalam Karangan Siswa Kelas VIII SMP Negeri 30 Semarang. Hasil penelitian ini menyatakan bahwa kesalahan berbahasa tataran frasa dalam karangan siswa kelas VIII SMP Negeri 30 Semarang meliputi kesalahan struktur frasa, salah karena berlebihan, penggunaan preposisi yang tidak tepat, salah pengulangan, penambahan kata tertentu pada frasa yang unsurnya tidak terpisahkan, dan penghilangan kata tertentu yang menghubungkan bagian-bagian frasa.

Berdasarkan uraian di atas, maka penulis tertarik mengangkat masalah ini sebagai topik penelitian dengan fokus masalah(1) Bagaimana kesalahan penggunaan sintaksis yang berupa frasa pada penulisan teks eksposisi siswa kelas X SMA Negeri 7 Medan tahun pembelajaran 2016/2017? (2) Bagaimana kesalahan penggunaan sintaksis yang berupa kalimat pada penulisan teks ekposisi siswa kelas X SMA Negeri 7 Medan tahun pembelajaran 2016/2017?

\section{ANALISIS KESALAHAN BERBAHASA TATARAN SINTAKSIS}

Analisis kesalahan mendasarkan prosedur kerja kepada data yang aktual dan masalah yang nyata.Anakes dianggap lebih efisien dan ekonomis dalam penyusunan rencana strategi pengajaran.Anakes dapat berfungsi sebagai dasar pengkajian prediksi Anakon dan sekaligus sebagai pelengkap hasil Anakon.

Analisis kesalahan berbahasa adalah prosedur kerja yang biasa digunakan oleh peneliti atau guru bahasa yang meliputi: kegiatan mengumpulkan sampel kesalahan, mengidentifikasi kesalahan yang terdapat dalam sampel, menjelaskan kesalahan tersebut, mengklasifikasi kesalahan tersebut, dan mengevaluasi taraf keseriusan kesalahan itu (Setyawati, 2013: 15).

"Analisis kesalahan adalah suatu prosedur kerja yang biasa digunakan oleh para peneliti dan guru bahasa, yang meliputi pengumpulan sampel, penjelasan kesalahan tersebut, pengklasifikasian kesalahan berdasarkan penyebabnya, serta 
pengevaluasian atau penilaian taraf keseriusan kesalahan itu." (Ellis dalam Tarigan, 2011: 60).

Kesalahan berbahasa dalam tataran frasa sering dijumpai dalam bahasa lisan maupun bahasa tertulis.Artinya, kesalahan berbahasa dalam bidang frasa ini sering terjadi dalam kegiatan berbicara maupun kegiatan menulis.

Istilah sintaksis secara langsung terambildari bahasa Belandasyntaxis. "Sintaksis ialah bagian atau cabang dari ilmu bahasa yang membicarakan seluk beluk wacana, kalimat, klausa, dan frasa, berbeda dengan morfologi yang membicarakan seluk-beluk kata dan morfem" (Ramlan, 2010: 17).

Kesalahan berbahasa dalam bidang frasa dapat disebabkan oleh berbagai hal,diantaranya: (a) adanya pengaruh bahasa daerah, (b) penggunaan preposisi yang tidak tepat, (c) kesalahan susunan kata, (d)penggunaan unsur yang berlebihan atau mubazir, (e) penggunaan superlatif yang berlebihan, (f) penjamakan ganda, dan (g) penggunaan bentuk resiprokal yang tidak tepat. (Setyawati, 2013:68)

Kriteriakesalahan penggunaan kalimat diklasifikasikan berdasarkan faktor penyebabnyayaitu: (a) kalimat yang tidak bersubjek, (b) kalimat yang tidak berpredikat, (c)kalimat yang buntung (tidak bersubjek dan tidak berpredikat), (d) antara predikat danobjek yang tersisipi, (e) kalimat yang tidak logis, (f) kalimat yang ambiguitas, (g)penghilangan konjungsi, (h) penggunaan konjungsi yang berlebihan, (i) urutankalimat yang tidak pararel, (j) penggunaan istilah asing, dan (k) penggunaan kata tanya yang tidak perlu (Setyawati, 2013: 76).

\section{METODE PENELITIAN}

Metode penelitian adalah suatu cara dalam proses pemecahan masalah dengan mengumpulkan dan menganalisis data untuk mencapai tujuan yang digunakan.Metode penelitian adalah cara yang digunakan oleh peneliti dalam mengumpulkan data penelitiannya(Arikunto,2013:203).Penelitian ini menggunakan pendekatan kualitatif .Pendekatan kualitatif adalah suatu proses penelitian dan pemahaman yang berdasarkan pada metodologi yang menyelidiki suatu fenomena sosial dan masalah manusia." (Iskandar, 2009: 11)."Penelitian kualitatif merumuskan masalah secara induktif, berdasarkan data di lapangan.Konsekuensinya, penelitian kuaitatif tidak berkutat dengan variabel dan teori." (Putra, 2013:45). Pengumpulan data yang dihasilkan dari penelitian 
ini bukanlah angka-angka, tetapi berupa kata-kata atau gambaran yang ditemukan di lapangan.Oleh karena itu, penelitian ini merupakan penelitian deskriptif kualitatif.

\section{HASIL PENELITIAN DAN PEMBAHASAN}

\section{Hasil Penelitian}

\section{a. Kesalahan Sintaksis Berupa Frasa}

Jumlah keseluruhan kalimat yang mengandung kesalahan sintaksis dari 38 teks siswa adalah sebanyak 94 kalimat dengan perincian 31 kalimat mengandung kesalahan penggunaan sintaksis berupa frasa. Hal tersebut diperoleh berdasarkan penyeleksian data yang telah dilakukan sebagai bagian dari proses analisis dengan membaca cermat dan berulang-ulang.

Dalam teks eksposisi siswa tersebut ditemukan enam faktor penyebab kesalahan penggunaan sintaksis berupa frasa. Keenam faktor penyebab kesalahan penggunaan sintaksis berupa frasa itu ditemukan dalam teks eksposisi siswa yaitu sebanyak 31 kalimat atau 32,98\% dari jumlah keseluruhan kalimat kesalahan sintaksis. Faktor penyebab kesalahan penggunaan sintaksis berupa frasa tersebut meliputi penggunaan preposisi yang tidak tepat (5 kalimat), susunan kata yang tidak tepat (8 kalimat), penggunaan unsur yang berlebihan atau mubazir (9 kalimat), penggunaan bentuk superlatif yang berlebihan (3 kalimat), penjamakan yang ganda (5 kalimat), dan penggunaan bentuk resiprokal yang salah (1 kalimat).

\section{b. Kesalahan Sintaksis Berupa Kalimat}

Jumlah keseluruhan kalimat yang mengandung kesalahan sintaksis dari 38 teks siswa adalah sebanyak 94 kalimat dengan perincian 63 kalimat mengandung kesalahan penggunaan sintaksis berupa kalimat. Hal tersebut diperoleh berdasarkan penyeleksian data yang telah dilakukan sebagai bagian dari proses analisis dengan membaca cermat dan berulang-ulang. 
Dalam teks eksposisi siswa tersebut ditemukan 7 (tujuh) faktor penyebab kesalahan penggunaan sintaksis berupa kalimat. Ketujuh faktor penyebab kesalahan penggunaan sintaksis berupa kalimat itu ditemukan dalam teks eksposisi siswa yaitu sebanyak 63 kalimat atau 67,02\% dari jumlah keseluruhan kesalahan sintaksis. Faktor penyebab kesalahan penggunaan sintaksis berupa kalimat tersebut meliputi : kalimat yang tidak berpredikat (1 kalimat), kalimat buntung (7 kalimat), kalimat yang tidak logis (17 kalimat), penggunaan kata tanya yang tidak perlu (3 kalimat), urutan yang tidak paralel (5 kalimat), penghilangan konjungsi (11kalimat), dan penggunaan konjungsi yang berlebihan (19 kalimat).

\section{Pembahasan Hasil Penelitian}

\section{a. Kesalahan Sintaksis Berupa Frasa}

Dalam teks eksposisi siswa kelas X SMA Negeri 7 Medan ditemukan sebanyak 31 kalimat atau 32,98\% dari jumlah keseluruhan kalimat kesalahan sintaksis. Diketahui bahwa kesalahan penggunaan unsur yang berlebihan atau mubazir pada teks eksposisi siswa jumlah frekuensinya lebih banyak dari pada bentuk kesalahan penggunaan struktur frasa yang lain. Hal ini menunjukkan bahwa kemampuan siswa dalam penggunaan unsur pada teks lebih rendah dari pada kemampuan menggunakan frasa yang lain.

Siswa tidak mengalami kesulitan saat menuliskan teks eksposisinya. Siswa mampu menuliskan teks eksposisi yaitu sesuai sudut pandang siswa terhadap pendidikan. Akan tetapi pada penelitian ini siswa banyak mengalami kesalahan penggunaan sintaksis berupa frasa pada penulisan teks eksposisi. Penggunaan unsur yang berlebihan atau mubazir adalah kesalahan penggunaan sistaksis berupa frasa terbanyak, hal ini disebabkan penggunaan unsur tidak dikuasai siswa dalam penulisan teks eksposisi siswa. Penguasaan penggunaan unsur sesuai kaidah bahasa Indonesia sudah diajarkan dalam proses pembelajaran oleh guru, namun siswa tidak mampu menguasai kaidah bahasa Indonesia tersebut karena ketidakbiasaan siswa menulis sesuai kaidah bahasa Indonesia. Tugas yang diberikan kepada siswa mengenai menulis teks telah terlaksana, tetapi guru tidak memiliki perhatian khusus mengenai penilaian 
kesalahan berbahasa tataran sintaksis. Siswa yang tidak menerima penilaian mengenai kesalahan sintaksis tersebut, siswa merasa bahwa ia sudah mampu menuliskan teks sesuai kaidah bahasa Indonesia, dengan demikian siswa tidak teliti dan berhati-hati dalam menuliskan setiap kata dalam teks. Siswa tidak menyadari bahwa penggunaan unsur yang sama digunakan sekaligus dalam kalimat adalah hal yang mubazir pemakaiannya.

\section{b. Kesalahan Sintaksis Berupa Kalimat}

Dalam teks eksposisi siswa tersebut ditemukan sebanyak 63 kalimat atau 67,02\% dari jumlah keseluruhan kesalahan sintaksis. Diketahui bahwa frekuensi penggunaan konjungsi yang berlebihan lebih banyak dari pada bentuk kesalahan penggunaan sintaksis berupa kalimat yang lain. Hal ini menunjukkan bahwa kemampuan siswa menggunakan konjungsi pada teksnya lebih rendah dari pada kemampuan menggunakan struktur kalimat lainnya.

Penggunaan struktur kalimat terkhusus penggunaan konjungsi yang berlebihan dikarenakan ketidaktelitian siswa dalam menuliskan kalimat pada teks.Ketidaktelitian ini terjadi akibat siswa tidak terbiasa menulis teks yang diberi pengoreksian mengenai kesalahan sintaksis oleh guru.Siswa tidak menyadari bahwa penggunaan konjungsi di awal kalimat adalah hal yang salah atau tidak sesuai kaidah bahas Indonesia.Siswa juga tidak menyadari bahwa penulisan dua konjungsi sekaligus tidak sesuai kaidah bahasa Indonesia.

Kesalahan penggunaan sintaksis berupa kalimat disebabkan kekurangpahaman siswa terhadap bahasa Indonesia.Penerapan kaidah yang tidak sempurna dapat dilihat dari hasil penelitian terdapatnya kesalahan sintaksis berupa kalimat.Siswa mendapat pengajaran bahasa yang kurang sempurna.Hal ini terjadi berkaitan dengan bahan yang diajarkan atau yang dilatihkan dalam pelaksanaan pengajaran belum maksimal menerapkan kaidah bahasa Indonesia.

Berdasarkan penelitian ini dapat dilihat bahwa siswa masih minim pemahaman penggunaan sintaksis dalam penulisan teks eksposisi.Siswa cukup pandai dalam 
mengargumentasikan pendapatnya pada tulisan tetapi penulisan yang dihasilkan masih belum sesuai dengan penggunaan sintaksis yang benar.

Pembelajaran bahasa Indonesia harus mampu membuat siswa memahami kaidah bahasa Indonesia secara tertulis, kemampuan ini bisa tercapai dengan kebiasaan siswa menggunakan bahasa Indonesia yang benar dengan ketelitian guru dalam memeriksa tugas atau hasil kerja siswa. Tugas yang diberikan kepada siswa mengenai menulis teks dengan memperhatikan kaidah penulisan bahasa Indonesia sangat berperan penting.

\section{PENUTUP}

Berdasarkan hasil temuan data dan pembahasan data penelitian mengenai analisis kesalahan berbahasa tataran sintaksis pada penulisan teks eksposisi siswa kelas X SMA Negeri 7 Medan Tahun Pembelajaran 2016/2017 dapat disimpulkan Kesalahan penggunaan sintaksis berupa frasa dalam teks eksposisi siswa kelas X SMA Negeri 7 Medan sebanyak 31 kalimat atau 32,98\%. Kesalahan penggunaan frasa tersebut meliputi : penggunaan preposisi yang tidak tepat, susunan kata yang tidak tepat, penggunaan unsur yang berlebihan atau mubazir, penggunaan bentuk superlatif yang berlebihan, penjamakan yang ganda, dan penggunaan bentuk resiprokal yang salah. Kesalahan penggunaan sintaksis berupa frasa terbanyak adalah penggunaan unsur yang berlebihan atau mubazir.

Kesalahan penggunaan sintaksis berupa kalimat dalam teks eksposisi siswa kelas X SMA Negeri 7 Medan sebanyak 63 kalimat atau 67,02\% . Kesalahan penggunaan struktur kalimat tersebut meliputi : kalimat yang tidak berpredikat, kalimat buntung, kalimat yang tidak logis, penggunaan kata tanya yang tidak perlu, urutan yang tidak paralel, penghilangan konjungsi, dan penggunaan konjungsi yang berlebihan. Kesalahan penggunaan sintaksis berupa kalimat terbanyak adalah penggunaan konjungsi yang berlebihan. 


\section{DAFTAR PUSTAKA}

Arikunto, 2013.Proses Penelitian Suatu Pendekatan Praktik. Jakarta: Rineka Cipta..

Iskandar, 2009.Metode Penelitian Kualitatif. Jakarta: Gaung Persada.

Istinganah, Nurul. 2012. Analisis Kesalahan Sintaksis Pada Karangan Narasi Ekspositoris Siswa Kelas VIII SMP Negeri 1 Banguntapan Bantul Yogyakarta.Yogyakarta:UNY.

Putra, Nusa. 2013. Metode Penelitian Kualitatif Pendidikan. Jakarta: Grafindo.

Ramlan,M. 2010.Sintaksis. Yogyakarta: Cv. Karyono.

Sari,Amalia Ayu.2013. Kesalahan Berbahasa Tataran Frasa Dalam Karangan Siswa Kelas VIII SMP Negeri 30 Semarang.Semarang :UNNES.

Sari, Nila.2002.Tesis.Analsisi Kesalahan Sintaksis Bahasa Indonesia Siswa Sekolah Dasar Di Kabupaten Karo Dalam Mengarang.Medan: Usu e-Repository.

Setyawati, Nanik. 2013. Analisis Kesalahan Berbahasa Indonesia Teori dan Praktik. Surakarta: Yuma Pustaka

Tarigan, 2013.Menulis Sebagai Suatu Keterampilan Berbahasa. Bandung: Angkasa. 1993. Pengajaran Sintaksis. Bandung: Angkasa.

Tarigan, Henry Guntur \& Djago Tarigan. 2011. Pengajaran Analisis Kesalahan Berbahasa. Bandung: Angkasa. 